\title{
CROP YIELD OF CONILON COFFEE PLANTS OF DIFFERENT LEVELS OF VEGETATIVE VIGOR AND RUST SEVERITY
}

\author{
RODRIGUES, Wagner Nunes ${ }^{1}$ \\ FERRÃO, Romário Gava ${ }^{2}$ \\ FERRÃ O, Maria Amélia Gava ${ }^{3}$ \\ FONSECA, Aymbiré Francisco Almeida da ${ }^{3}$ \\ MENDONÇA, Rodolfo Ferreira de ${ }^{4}$ \\ MARTINS, Lima Deleon ${ }^{1}$ \\ TOMAZ, Marcelo Antonio ${ }^{5}$
}

\begin{abstract}
SUMMARY: The breeding programs have sought to provide rust-resistant cultivars, since the genetic control is the most economical and efficient method of management of this plant disease. This study investigated the relationship between the rust severity, vigor and crop yield capacity of conilon coffee plants. The experiment was conducted in the Experimental Farm of Bananal do Norte (INCAPER), located in Cachoeito de Itapemirim, in the southern state of Espírito Santo. The crop yield was evaluated in 20 combinations of 4 levels of vigor and 5 levels of rust severity. The experimental design used was in randomized blocks, with four replications and 5 plants per plot. There was the formation of five groups of homogeneous means for the combinations and the means was adjusted to a response surface model. The combinations between the levels of vigor and rust severity influenced the crop yield of conilon coffee in the evaluated conditions. The vegetative vigor factor was the more limiting than the rust severity in determining the coffee plants yield.
\end{abstract}

Keywords: Coffea canephora. Hemileia vastatrix. Development. Yield

\section{PRODUTIVIDADE DE PLANTAS DE CAFÉ CONILON DE DIFERENTES NÍVEIS DE VIGOR VEGETATIVO E SEVERIDADE DA FERRUGEM}

\begin{abstract}
RESUMO: Os programas de melhoramento genético têm buscado disponibilizar cultivares resistentes à ferrugem, visto que o controle genético constitui o método mais econômico e eficiente no manejo dessa doença. Este trabalho objetivou estudar a relação entre a severidade da ferrugem, o vigor vegetativo e a capacidade produtiva de plantas de café conilon. O experimento foi realizado na Fazenda Experimental de Bananal do Norte (INCAPER), localizada em Cachoeiro de Itapemirim, no sul do Estado do Espírito Santo. Foram avaliadas as produtividades de 20 combinações entre 4 níveis de vigor vegetativo e 5 níveis de severidade da ferrugem. O delineamento experimental utilizado foi em blocos casualizados com 4 repetições e 5 plantas por parcela experimental. Verificou-se a formação de cinco grupos de médias homogêneas para as combinações e ajustou-se as médias a um modelo de superfície de resposta. As combinações entre os níveis de vigor vegetativo e severidade da ferrugem influenciaram a produtividade do cafeeiro conilon nas condições avaliadas. O fator vigor vegetativo foi mais limitante que o fator severidade da ferrugem na determinação da produtividade de plantas de café conilon.
\end{abstract}

\footnotetext{
${ }^{1}$ M. Sc., Doctor degree student, Programa de Pós-Graduação em Produção Vegetal do Centro de Ciências Agrárias da Universidade Federal do Espírito Santo (CCA/UFES), Alto Universitário, s/n, Cx Postal 16, Bairro Guararema, CEP: 29500-000, Alegre, ES, Brazil, E-mail: wagnernunes86@hotmail.com, deleon_lima@ hotmail.com;

${ }^{2}$ D. Sc., Researcher, Instituto Capixaba de Pesquisa, Assistência Técnica e Extensão Rural (INCAPER), Rua Afonso Sarlo, 160, Bento Ferreira, CEP: 29052-010, Vitória, ES, Brazil, E-mail: romario@ incaper.es.gov.br;

${ }^{3}$ D. Sc., Researcher, Empresa Brasileira de Pesquisa Agropecuária (EMBRAPA CAFÉ/INCAPER), Parque Estação Biológica, PqEB, s/n, CEP: 70770-901, Brasília, DF, Brazil, E-mail: maria.ferrao@embrapa.br, aymbire.fonseca@embrapa.br;

${ }^{4}$ Master degree student, Programa de Pós-Graduação em Produção Vegetal do Centro de Ciências Agrárias da Universidade Federal do Espírito Santo (CCA/UFES), Alto Universitário, s/n, Cx Postal 16, Bairro Guararema, CEP: 29500-000, Alegre, ES, Brazil, E-mail: rfmendonca_br@yahoo.com.br;

${ }^{5}$ D. Sc., Professor, Departamento de Produção Vegetal do Centro de Ciências Agrárias da Universidade Federal do Espírito Santo (CCA/UFES), Alto Universitário, s/n, Cx Postal 16, Bairro Guararema, CEP: 29500-000, Alegre, ES, Brazil,E-mail: tomaz@cca.ufes.br.
} 
Palavras-chave: Coffea canéfora. Hemileia vastatrix. Desenvolvimento. Produção

\section{INTRODUCTION}

The coffee leaf rust is a disease that appears in all regions of the world where coffee is cultivated. The disease is caused by Hemileia vastratrix, a biotrophic fungus that occurs widely throughout the State of Espírito Santo (VENTURA et al., 2007). This disease is considered the most important for coffee plantations and it is the result of a dynamic process, with an infection that is not standardized, being dependent on several factors ranging from weather conditions in the region to the physiological state of the coffee plants (GODOY et al., 1997; MARTINS et al., 2009).

This disease can cause premature fall of leaves, which results in delaying the growth of young plants and in languishing of older plants (ZAMBOLIM et al., 2005).

The self-incompatibility and allogamy observed in conilon coffee are responsible for the high genetic variability found among individuals, this fact contributes to the formation of heterogeneous populations for rust resistance (BRAGANÇA et al., 1993; SILVA et al., 2000). The rust symptoms may vary depending on the susceptibility of each genotype to this disease, causing differences in the lesions sizes, in the percentage of diseased leaf area and in the fungus sporulation (BECKER-RATERINK, 1991; FERRÃO et al., 2007a).

The presence of chlorotic or yellow spots without fungus sporulation are indicative of the expression of resistance in coffee plants. The resistance is considered to be intermediate in cases of chlorotic spots with little sporulation or small pustules (VENTURA et al., 2007).

In some clones of conilon coffee, the coalescence of several spots and the premature leaf fall may occur; but in some other clones, the leaves don't fall even at high severity of the disease (VENTURA et al., 2007).

The current strategies for disease management in coffee plantations consider genetic factors of the host, pathogen evolution and epidemiology of diseases to ensure the sustainability of the production systems (FERRÃO et al., 2007a).

Several research institutions have been working with coffee breeding in Brazil, searching for new cultivars with the greatest rust resistance associated with the maintenance or improvement of plant vigor and crop yield already achieved in the genetic materials actually used in the plantations (MATIELLO et al., 2008).

The constant search for cultivars resistant or tolerant to rust is based in the great advantages of the genetic control for the disease. The genetic control is the most economical and efficient management of the coffee rust, minimizing the environmental impacts and reducing the application of chemicals products (VENTURA et al., 2007).

This study investigated the relationship between rust severity, vegetative vigor and crop yield capacity of conilon coffee plants.

\section{MATERIAL AND METHODS}

The experiment was conducted at the Experimental Farm of Bananal do Norte (INCAPER), located in the city of Cachoeiro de Itapemirim, $20^{\circ} 45^{\prime} \mathrm{S}$ and $41^{\circ} 17^{\prime} \mathrm{W}$, south of Espírito Santo state. The region's climate is classified as $\mathrm{Cwa}$, with rainy summer and dry winter according to the classification of Köpen, with annual rainfall of $1,200 \mathrm{~mm}$, mean annual temperature of $23{ }^{\circ} \mathrm{C}$, altitude of $140 \mathrm{~m}$, wavy 
topography and soil classified as Red-Yellow Oxisol. The plants spacing used was $3.00 \times 1.20 \mathrm{~m}$, and the entire management system was designed according to the current recommendations for conilon coffee in the state of Espírito Santo (FERRÃO et al., 2007b; PREZOTTI et al., 2007).

The treatments consisted of 20 combinations of four levels of plant vigor and five levels of rust severity (Table 1). A random selection was made among the numerous genetic materials actually being used and evaluated in the breeding program, finding genotypes that would satisfy the conditions for the treatments. This selection was performed according to the historic of each genotype along the years for severity of the leaf rust and vegetative vigor.

Table 1. Combinations between the levels of vegetative vigor and rust severity.

\begin{tabular}{cll}
\hline Combination & \multicolumn{1}{c}{ Vegetative Vigor (VIG) } & \multicolumn{1}{c}{ Rust Severity (RUS) } \\
\hline 1 & 3 (Depleted plants) & 1 (No visible symptoms) \\
2 & 3 (Depleted plants) & 3 (A few pustules) \\
3 & 3 (Depleted plants) & 5 (Moderate infection, without defoliation) \\
4 & 3 (Depleted plants) & 7 (High infection, abundant pustules, with defoliation) \\
5 & 3 (Depleted plants) & 9 (Very severe symptoms, with high defoliation) \\
6 & 5 (Plants of intermediate vigor) & 1 (No visible symptoms) \\
7 & 5 (Plants of intermediate vigor) & 3 (A few pustules) \\
8 & 5 (Plants of intermediate vigor) & 5 (Moderate infection, without defoliation) \\
9 & 5 (Plants of intermediate vigor) & 7 (High infection, abundant pustules, with defoliation) \\
10 & 5 (Plants of intermediate vigor) & 9 (Very severe symptoms, with high defoliation) \\
11 & 7 (Vigorous plants) & 1 (No visible symptoms) \\
12 & 7 (Vigorous plants) & 3 (A few pustules) \\
13 & 7 (Vigorous plants) & 5 (Moderate infection, without defoliation) \\
14 & 7 (Vigorous plants) & 7 (High infection, abundant pustules, with defoliation) \\
15 & 7 (Vigorous plants) & 9 (Very severe symptoms, with high defoliation) \\
16 & 9 (Plants of excellent vigor) & 1 (No visible symptoms) \\
17 & 9 (Plants of excellent vigor) & 3 (A few pustules) \\
18 & 9 (Plants of excellent vigor) & 5 (Moderate infection, without defoliation) \\
19 & 9 (Plants of excellent vigor) & 7 (High infection, abundant pustules, with defoliation) \\
20 & 9 (Plants of excellent vigor) & 9 (Very severe symptoms, with high defoliation) \\
\hline
\end{tabular}

The selected genotypes were placed in a experimental field following a randomized block design, with four replications and five plants per plot. The plants were cultivated until the end of the vegetative cycle and passed the three first reproductive cycles, giving time to each genotype express its characteristics, before the evaluations were performed, five years after plantation, along their fourth productive cycle.

The vegetative vigor and rust severity were reevaluated to check if the genotypes expressed the expected levels to the correct formation of each combination, matching the criteria for the yield evaluations.

The vegetative vigor (VIG) was evaluated using a descriptive scale with grades increasing from 1 to 10 , where higher scores are associated with improved plant vegetative development. The severity of coffee leaf rust (RUS) was evaluated from May to August of 2009, according the method used by Eskes ; Costa (1983), establishing different levels of severity between the note 1, corresponding to lack of rust damage, and the note 9, indicating a large amount of sick leaves or branches, with many sporulated pustules and significant leaf fall. The crop yield (YIE) was estimated, in bags of 60 kilograms per hectare $\left(\mathrm{sc} \mathrm{ha} \mathrm{C}^{-1}\right.$ ), by determining the weight of coffee cherries produced in each group of plants.

The data were subjected to variance analysis using the statistical software GENES (CRUZ, 2006). The response surface model was selected according to the significance of the regression coefficients, 
adorned by Student's $t$ test at $5 \%$ of probability, and the determination coefficient $\left(\mathrm{R}^{2}\right)$, and was made using the software SigmaPlot ${ }^{\circledR}$ version 11.0.

\section{RESULTS AND DISCUSSION}

Through the Scott-Knott test $(\mathrm{p} \leq 0.05)$, there was the formation of five groups of homogeneous means for the combinations between the levels of vegetative vigor and severity of the coffee leaf rust in the evaluated plants (Table 2).

Table 2. Mean values for crop yield of conilon coffee plants in relation to each level of vegetative vigor and rust severity.

\begin{tabular}{ccccc}
\hline \multirow{2}{*}{ Combination } & \multicolumn{3}{c}{ Factors } & \multicolumn{2}{c}{$\begin{array}{c}\text { Crop Yield } \\
\left(\text { sc ha- }^{-1}\right)\end{array}$} \\
\cline { 2 - 3 } & Vegetative Vigor & Rust Severity & $106.41 \mathrm{c}$ \\
2 & 3 & 1 & $155.03 \mathrm{~b}$ \\
3 & 3 & 3 & $169.45 \mathrm{a}$ \\
4 & 3 & 5 & $186.93 \mathrm{a}$ \\
5 & 3 & 7 & $195.04 \mathrm{a}$ \\
6 & 3 & 9 & $35.30 \mathrm{e}$ \\
7 & 5 & 1 & $49.49 \mathrm{~d}$ \\
8 & 5 & 3 & $53.23 \mathrm{~d}$ \\
9 & 5 & 5 & $97.45 \mathrm{c}$ \\
10 & 5 & 7 & $92.20 \mathrm{c}$ \\
11 & 5 & 9 & $23.09 \mathrm{e}$ \\
12 & 7 & 1 & $29.20 \mathrm{e}$ \\
13 & 7 & 3 & $97.93 \mathrm{c}$ \\
14 & 7 & 5 & $95.70 \mathrm{c}$ \\
15 & 7 & 7 & $85.86 \mathrm{c}$ \\
16 & 7 & 9 & $61.96 \mathrm{~d}$ \\
17 & 9 & 1 & $67.12 \mathrm{~d}$ \\
18 & 9 & 3 & $114.35 \mathrm{c}$ \\
19 & 9 & 5 & $132.72 \mathrm{~b}$ \\
20 & 9 & 7 & $140.83 \mathrm{~b}$ \\
\hline
\end{tabular}

Means followed by the same letter, between combinations, do not differ from each other by the Scott-Knott test at $5 \%$ of probability $(\mathrm{CV}=21,40 \%)$.

The combinations 3, 4 and 5 had higher mean values for crop yield, respectively $169.45,186.93$ and $195.04 \mathrm{sc} \mathrm{ha}^{-1}$, forming the group of statistically superior means. The combinations 2, 19 and 20 were placed in the second group of means according to the Scott-Knott criteria, with mean values between 132.72 and $155.03 \mathrm{sc} \mathrm{ha}^{-1}$. The third homogeneous group was formed by the combinations $1,9,10,13,14$, 15 and 18, reaching means between 85.86 and $114.35 \mathrm{sc} \mathrm{ha}^{-1}$. The combinations 7, 8, 16 and 17 formed the fourth group of similar means, with crop yield between 49.49 and $67.12 \mathrm{sc} \mathrm{ha}^{-1}$. The inferior group was formed by the combinations 6,11 and 12, with means for yields of less than $35.30 \mathrm{sc} \mathrm{ha}^{-1}$.

Overall, it can be observed high productions from genotypes that have a fast recovery rate, keeping a high vigor even with the high fruit load; and also from genotypes that have a noticeable reduction on the vigor due to the metabolic stress of the high fruit load. In both cases, the crop yield is high and the vigor of those genotypes depends on the recovery rate. Therefore, it is possible that plants with high yield along the years present lower vigor, due the slow vegetative recuperation, being able to keep a satisfactory yield as long as those plants are not subjected to others stresses, from which those genotypes could not be able to recover. 
Examining the Figure 1, it is possible to note the existence of a superior influence between plant vigor and crop yield, indicated by the slope gradients of the lines that form the response surface being more pronounced for the factor VIG compared to the factor RUS. This result indicates that the vegetative vigor was most limiting to the crop yield of the coffee plants than the severity of the leaf rust.

Other authors have cited factors related to the vegetative vigor of coffee plants, such as the leaf development, and the crop yield influencing the evolution of the coffee leaf rust (MATIELO; ALMEIDA, 2006).

The relation between the increase of the disease severity due to the increased production of coffee fruits is associated with the stress caused by the load status of the plants (MARTINS et al., 2009), which weakens the resistance of plants to the development of the pathogen. It is believed that the drainage of the fotoassimilates from the leaves to the coffee fruits during the production process is one of the causes due witch the vigor of the plant is adversely affected, resulting in the increase of the disease severity (ZAMBOLIM et al., 1997).

However, the relation rust $\mathrm{x}$ yield in coffee plants is yet not well known and it is still an important focus of study and research. Ferrão et al. (2007c) highlight the need for deeper studies on this subjectn, especially considering the high crop yield capacity of the clones that compose the current clonal cultivars of conilon coffee.

Figure 1. Response surface for crop yield (YIE), in sc ha ${ }^{-1}$, of conilon coffee plants, influenced by vegetative vigor (VIG) and the rust severity (RUS).

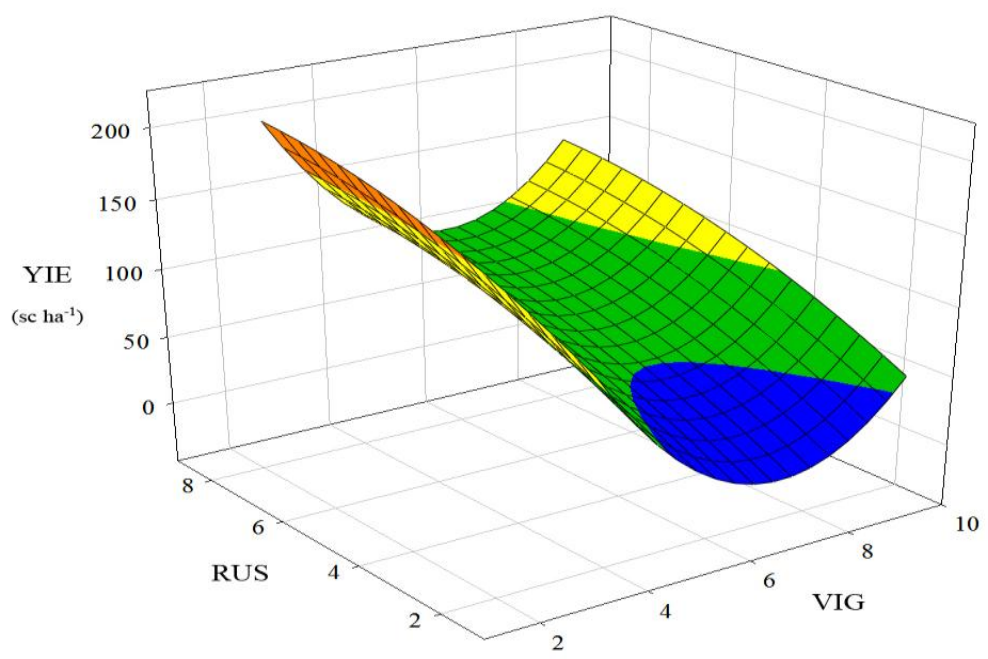

The adjustment of the response surface to the equational model is shown by the linear regression analysis in Table 3, which presents the significance of the adopted model, the statistical significance of the regression coefficients (betas), and the appropriate coefficient of determination $\left(\mathrm{R}^{2}\right)$.

Table 3. Regression analysis.

\begin{tabular}{|c|c|c|}
\hline Model sign. & Regression equation & $\mathbf{R}^{2}$ \\
\hline $\mathrm{p}<0,0001$ & PROD $=347,7618^{*}-109,3942^{*} . \mathrm{VIG}+18,8558^{*} \cdot \mathrm{FER}+8,3799^{*} \cdot \mathrm{VIG}^{2}-0,9027^{\mathrm{ns}} \cdot \mathrm{FER}^{2}$ & 0,96 \\
\hline
\end{tabular}

\section{CONCLUSIONS}

The combinations between levels of vegetative vigor and levels of the leaf rust severity influence the crop yield of conilon coffee. 
The vegetative vigor is more limiting than the leaf rust severity to determine the crop yield in conilon coffee plants.

\section{REFERENCES}

BECKER-RATERINK, S. El sistema Coffea spp y Hemileia vastatrix. In: BECKER-RATERINK, S.; MORAES, W. B.; QUIJANO-RICO, M. La roya del cafeto: conocimiento y control. Eschborn: GTZ, 1991, p. 2-63.

BRAGANÇA, S. M.et al. EMCAPA 8111, EMCAPA 8121, EMCAPA 8131. Primeiras variedades clonais de café conilon lançadas para o Espírito Santo. Vitória: EMCAPA, 1993. 2 p.

CRUZ, C. D. Programa GENES: estatística experimental e matrizes. Viçosa: UFV, 2006. 285p.

ESKES, A. B.; COSTA, W. M. Characterization of incomplete resistance to Hemileia vastatrix in the Icatu coffee population. Euphytica, Wageningen, v.32, p.649-657, 1983.

FERRÃO, M. A. G.et al. Origem, dispersão geográfica, taxonomia e diversidade genética de Coffea canephora. In: FERRÃO, R. G.et al. Café conilon. Vitória: Incaper, 2007a. p. 65-92.

FERRÃO, R. G.et al. Café Conilon. Vitória: Incaper, 2007b. 702p.

FERRÃO, R. G. et al. Café conilon: técnicas de produção com variedades melhoradas. 3 ed. Vitória: Incaper, 2007c. 60p.

GODOY, C. V.; BERGAMIN FILHO, A.; SALGADO, C. L. Doenças do cafeeiro. In: KIMATI, H.et al. Manual de fitopatologia. v. 2. 3. ed. São Paulo: Ceres. 1997. p.184-200.

MATIELLO, J. B.; ALMEIDA, S. R. A ferrugem do cafeeiro no Brasil e seu controle. Varginha: MAPA/PROCAFÉ/EMBRAPA-Café, 2006. 106p.

MATIELLO, J. B.et al. Japi e Arara, duas novas variedade de café com resistência à ferrugem e boa produtividade. In: CONGRESSO BRASILEIRO DE PESQUISAS CEFEEIRAS, 34., Caxambu, 2008. Anais... Varginha: PROCAFÉ, 2008. 4-5p.

MARTINS, A. N.; SILVEIRA, A. P.; FURTADO, E. L. Avaliação do cloreto de benzalcônio no controle da ferrugem (Hemileia vastatrix Berk. ; Br.) do cafeeiro (Coffea arabica L.). Summa Phytopathologica, v. 35, n. 2, p. 143-145, 2009.

PREZOTTI, L. C.et al. de. Manual de recomendação de calagem e adubação para o Estado do Espírito Santo: $5^{a}$ aproximação. Vitória: SEEA/INCAPER/CEDAGRO, 2007. 305p.

SILVA, D. G. da et al. Resistência de clones de Coffea canephora var. Conilon a quatro raças de Hemileia vastatrix Berk. et Br. In: SIMPÓSIO DE PESQUISA DOS CAFÉS DO BRASIL, 2000, Poços de Caldas. Anais... Brasília: Embrapa Café/ MINASPLAN, 2000. v. 1. p. 192-196.

VENTURA, J. A.et al. Diagnóstico e manejo das doenças do cafeeiro conilon. In: FERRÃO, R. G.et al. Café conilon. Vitória: Incaper, 2007. p. 451-498.

ZAMBOLIM, L.et al. Café (Coffea arabica L.), controle de doenças causadas por fungos, bactérias e vírus. In: VALE, F. X. R.; ZAMBOLIM, L. Controle de doenças de plantas. Viçosa: Suprema Gráfica e Editora, 1997. p.83-180.

ZAMBOLIM, L. VALE, F. X. R.; ZAMBOLIM, E. M. Doenças do cafeeiro. In: KIMATI, H.; et al. Manual de fitopatologia. 4 ed. São Paulo: Agronômica Ceres, 2005. 